\title{
HUBUNGAN ANTARA SECURE ATTACHMENT DAN KECERDASAN ADVERSITAS DENGAN MOTIVASI BERPRESTASI PADA SISWA SINGLE PARENT
}

\author{
Mutia Hafidhyah Rohmah \\ Fajar Kawuryan \\ Latifah Nur Ahyani \\ Fakultas Psikologi Universitas Muria Kudus \\ fajrihidayat_ok@yahoo.com \\ latifah.nur@umk.ac.id
}

\begin{abstract}
Abstrak
Penelitian ini bertujuan untuk mengetahui hubungan secure attachment dan kecerdasan adversitas dengan motivasi berprestasi pada siswa single parent. Subyek penelitian ini adalah 36 siswa di SMAN 1 Bangsri. Teknik pengambilan sampel pada penelitian ini menggunakan teknik studi populasi. Alat ukur yang digunakan untuk memperoleh data adalah skala secure attachment, skala kecerdasan adversitas, dan skala motivasi berprestasi. Hasil analisis data dengan menggunakan Analisis Regresi program SPSS 15,0for windows diperoleh hasil koefisien korelasi dari ketiga variabel rx1,2y sebesar 0,832 dengan $p$ sebesar 0,000 $\quad p<0,01$ ) ini berarti ada hubungan yang sangat signifikan antara secure attachment dan kecerdasan adversitas dengan motivasi berprestasi. Dengan demikian hipotesis mayor dalam penelitian ini diterima. Hasil koefisien korelasi antara variabel secure attachment dengan motivasi berprestasi rx1y sebesar 0,802 dengan $p$ sebesar 0,000 $\mathrm{p}<0,01$ ) ini berarti ada hubungan positif yang sangat signifikan antara secure attachment dengan motivasi berprestasi pada siswa single parent, dengan demikian hipotesis yang diajukan dalam penelitian ini diterima. Sedangkan koefisien korelasi antara variabel kecerdasan adversitas dengan motivasi berprestasi rx2y sebesar 0,795 dengan taraf signifikan $p$ sebesar $0,000 \quad p<0,01$ ) ini berarti ada hubungan positif yang sangat signifikan antara kecerdasan adversitasdengan motivasi berprestasi, dengan demikian hipotesis yang diajukan dalam penelitian ini diterima. Sumbangan efektif variabel bebas terhadap variabel terikat sebesar $69,3 \%$.
\end{abstract}

Kata kunci: secure attachment, kecerdasan adversitas, motivasi berprestasi.

Terwujudnya motivasi berprestasi pada anak perlu dukungan dan perhatian dari keluarga terutama dari kedua orang tua. Keluarga merupakan satu kesatuan lingkungan sosial pertama bagi anak dan tempat anak mendapatkan perlindungan, kasih saying, serta rasa aman (Sari, 2011).

Kehadiran orang tua pada perkembangan jiwa anak sangatlah penting. Anak yang kehilangan peran dan fungsinya maka proses tumbuh kembangnya pun akan kehilangan hak untuk dibina dan dibimbing, diberikan kasih sayang, perhatian, dan sebagainya. Kematian salah satu orang tua akan mempengaruhi perkembangan 
mental anak (Lestari, 2008). Dengan hilangnya salah satu orang tua yang berarti dalam hidupnya, anak-anak akan merasa dirugikan. Anak-anak yang hanya memiliki orang tua tunggal (single parent) cenderung kurang mampu mengerjakan sesuatu hal dengan baik dibanding dengan anak-anak dari keluarga yang orang tuanya utuh (Isti'anah, 2010)

Remaja yang tinggal dengan orang tua tunggal menghadapi tantangan dan masalah seperti kehilangan sumber ekonomi, rendahnya keterlibatan dan dorongan orang tua, dan kurangnya dukungan emosional dari orang tua yang mana mempengaruhi motivasi berprestasi akademik mereka (Kamla dalam Sitota, 2014).

Menurut hasil penelitian Sokun \& Akinade (Obieke, 2013) anak yang tinggal dan diasuh dengan satu orang tua memiliki self esteem, motivasi berprestasi, dan prestasi akademik yang rendah dibanding dengan meraka dari keluarga yang lengkap, dimana keduanya yaitu ayah dan ibu menjadi orang tua.

Salah satu bentuk keterikatan kasih sayang yang dimulai dari kehidupan individu adalahsecure attachment. Secure attachment merupakan keterikatan yang aman berupa kasih sayang yang diberikan orangtua pada anak secara konsisten dan responsif dalam menumbuhkan rasa aman dan kasih sayang" (Maentiningsih, 2008).

Remaja yang matang secara fisik dan emosi tidak terlepas dari dukungan dan kasih sayang orang tua dalam bentuk keterikatan yang aman (secure attachment). Remaja dengan secure attachment akan terpenuhi rasa aman dan kasih sayang dari orangtua sehingga mampu mencapai kebutuhan penghargaan dari orang lain (aktualisasi diri) khususnya dalam bentuk prestasi” (Maentiningsih, 2008).

Menurut Stoltz, kecerdasan adversitas adalah suatu kemampuan untuk mengubah hambatan menjadi suatu peluang keberhasilan mencapai tujuan. Kecerdasan adversitas mempengaruhi pengetahuan, kreativitas, produktivitas, kinerja, usia, motivasi, pengambilan resiko, perbaikan, energi, vitalitas, stamina, kesehatan, dan kesuksesan dalam pekerjaan yang dihadapi (Syahid, 2014).

McClelland (Djaali, 2014) mengungkapkan bahwa motivasi berprestasi merupakan motivasi yang berhubungan dengan pencapaian beberapa standar keahlian. Heckhausen (Djaali, 2014), motivasi berprestasi adalah suatu dorongan yang terdapat dalam diri siswa yang selalu berusaha atau berjuang untuk meningkatkan atau memlihara kemampuannya setinggi mungkin dalam semua aktifitas dengan menggunakan standar keunggulan.

Kinchella dan Glucksberg (Mahmoud, 2001) mengatakan bahwa motivasi berprestasi meliputi keinginan untuk melakukan pekerjaan yang sulit, menghadapi kriteria tinggi dan mengungguli orang lain. 
Menurut Winkel (Hartaji, 2009), motivasi berprestasi merupakan daya penggerak dalam diri siswa untuk mencapai taraf prestasi akademik yang setinggi mungkin demi penghargaan kepada diri sendiri. Dalam mencapai prestasi yang setinggi mungkin, setiap individu harus memiliki keinginan yang kuat demi mencapai tujuanya. Dimana hal itu sangat tergantung pada usaha, kemampuan, dan kemauan dari individu itu sendiri.

Menurut Asnawi (2001) ada empat aspek-aspek motivasi berprestasi yaitu

a. Mengambil tanggung jawab atas perbuatannya

Individu dengan motivasi berprestasi tinggi merasa dirinya bertanggung jawab terhadap tugas yang dikerjakanya. la akan berusaha untuk menyelesaikan setiap tugas yang dilakukan dan tidak akan meninggalkan sebelum menyelesaikan tugasnya.

b. Memperhatikan umpan balik tentang perbuatannya

Pada individu dengan motivasi berprestasi tinggi, pemberian umpan balik atas hasil usaha atau kerjanya yang telah dilakukan sangat disukai dan berusaha untuk melakukan perbaikam hasil kerja yang akan datang.

c. Mempertimbangkan resiko

Individu dengan motivasi berprestasi tinggi cenderung mempertimbangkan resiko yang akan dihadapinya sebelum memulai pekerjaan. la akan memilih tugas dengan derahat kesukaran sedang, yang menantang kemampuannya, namun amsih memungkinkan untuk berhasil menyelesaikan dengan baik.

d. Kreatif-inovatif

Individu dengan motivasi berprestasi tinggi cenderung bertindak kreatif, dengan mencari cara baru untuk menyelesaikan tugas seefektif dan seefisien mungkin.

Helmi (Fahmi, 2008) dalam penelitiannya menyebutkan faktor-faktor yang dapat mempengaruhi motivasi berprestasi, diantaranya kompetitif, dukungan sosial, dukungan emosional, sikap optimis yang dimiliki, dan lingkungan sekitar.

Kusuma dkk (2000), individu yang memiliki motivasi berprestasi tinggi ketika dikondisikan pada sebuah situasi tertentu atau konflik, maka individu tersebut akan menjadi individu-individu yang produktif, mandiri, dan selalu termotivasi untuk berprestasi lebih baik (Fahmi, 2008).

Lingkungan yang merupakan segala sesuatu yang berada di luar individu yang dalam hal ini meliputi lingkungan keluarga, sekolah, kelompok sebaya (peer group), dan masyarakat secara potensial mempengaruhi dan dipengaruhi oleh perkembangan individu (Fahmi, 2008). 
Single parent adalah keluarga yang terdiri dari orang tua tunggal yang hanya terdiri dari ibu dan ayah saja yang disebabkan karena perceraian atau salah satunya meninggal dunia sehingga seluruh tugas dan tanggung jawab dibebankan kepada yang ditinggalkan (Isti'anah, 2010).

Berdasarkan uraian di atas diperoleh kesimpulan bahwa motivasi berprestasi siswa single parent adalah suatu dorongan, keinginan dan daya penggerak individu dari keluarga yang terdiri dari orang tua tunggal yaitu ayah atau ibu untuk mencapai sebuah standart, kriteria atau taraf prestasi akademi yang setinggi mungkin demi penghargaan kepada diri sendiri.

Menurut Ainsworth, secure attachment adalah keterikatan yang aman secara emosional antara orangtua dengan anak dan sebagai dasar perkembangan psikologis (Rohmawati, 2011).

Menurut Mikulincer, secure attachment adalah kepercayaan pada kesediaan figure attachment disaat dibutuhkan, nyaman dengan kedekatan saling membutuhkan dan saling percaya. Papalia juga mengemukakan pengertian secure attachment yaitu pola attachment dimana anak menangis anak merasa percaya pada pengasuh sebagai figur yang selalu siap mendampingi dan responsif, penuh cinta dan kasih sayang ketika anak mencari perlindungan atau kenyamanan, dan selalu menolong atau membantunya dalam menghadapi situasi yang mengancam dan menakutkan (Rohmawati, 2010).

Sedangkan menurut Morrison menyatakan secure attachment adalah keterikatan yang aman berupa kasih sayang yang diberikan orangtua pada anak secara konsisten dan responsif sehingga menumbuhkan rasa aman dan kasih sayang. Menurut Pennington mengatakan bahwa secure attachment akan mengarah pada pengembangan rasa percaya diri, sikap atau ego yang kuat sehingga akan menentukan kesuksesan dalam menghadapi berbagai masalah (Rohmawati, 2010).

Menurut Benokraitis (1996), karakteristik individu yang memiliki secure attachment yaitu:

a. Sikap hangat dalam berhubungan dengan orang lain.

Individu dengan secure attachment cenderung lebih bersikap hangat dalam hal ini lebih ramah dalam berhubungan dengan orang lain, baik dalam lingkungan keluarga ataupun dalam hal pertemanan.

b. Tidak terlalu bergantung pada orang lain.

Individu dengan secure attachment sangat mandiri karena tidak selalu bergantung dengan orang lain. Umumnya individu yang secure attachment merasa yakin dalam melakukan sesuatu hal dan kemampuan akan dirinya karena mendapat kasih sayang yang cukup dari keluarganya. 
c. Tidak akan menjauhi orang lain.

Individu dengan secure attachment cenderung tidak akan menjauhi orang lain, lebih terbuka dengan orang lain. Individu yang secure attachment mampu menjalin hubungan dengan orang disekitarnya.

d. Sangat dekat dengan orang yang sangat disayanginya.

Individu dengan secure attachment biasanya sangat dekat dengan orang yang disayanginya dalam hal ini adalah orangtua dan keluarga. Individu yang secure attachment juga umumnya sangat dekat dengan dengan saudara kandungnya seperti kakak atau adik.

e. Lebih empati terhadap orang lain.

Individu dengan secure attachment lebih empati dengan orang lain karena individu yang secure attachment memiliki rasa sosial yang tinggi.

f. Sangat percaya pada orang yang disayangi.

Individu dengan secure attachment cenderung lebih percaya terhadap orang yang disayanginya seperti orangtua dan keluarga karena individu yang secure attachment memiliki hubungan yang sangat dekat dan didasari oleh kasih sayang yang sangat kuat dengan keluarganya.

g. Lebih nyaman bersama orang yang disayangi.

Individu dengan secure attachment lebih nyaman untuk menghabiskan waktu bersama dengan orang-orang yang disayanginya seperti keluarganya.

Menurut Stoltz (2000), kecerdasan adversitas adalah kecerdasan untuk menghadapi kesulitan dan kemampuan bertahan dalam berbagai tantangan yang dihadapi. Kecerdasan adversitas merupakan gambaran kebiasaan individu dalam merespon kesulitan dan ukuran pola bawah sadar yang konsisten yang telah dikembangkan selama bertahun-tahun. Kecerdasan adversitas menjadi variabel yang menentukan apakah individu tetap menaruh harapan dan terus memegang kendali dalam situasi yang sulit. Kecerdasan adversitas juga merupakan kemampuan individu untuk menggerakkan tujuan hidup ke depan.

Kecerdasan adversitas merupakan pemahaman penting tentang apa yang dibutuhkan untuk mencapai kesuksesan. Sukses atau tidaknya individu dalam kehidupan ditentukan oleh kecerdasan adversitas, karena kecerdasan adversitas mampu memperlihatkan sejauh mana individu mampu bertahan dan mengatasi kesulitan yang dihadapinya, individu mana yang mampu atau tidak mampu mengatasi kesulitan, individu mana yang akan berhasil atau gagal dalam memenuhi harapan dan potensi, dan individu yang akan menyerah dan yang akan bertahan. (Stoltz, 2000). 
Menurut Stoltz (2000), "setiap individu memiliki kecerdasan adversitas yang tinggi dan rendah". Adapun karakteristik individu yang memiliki kecerdasan adversitas tinggi antara lain:

a. Optimis, gigih, dan ulet dalam menghadapi masalah.

b. Berpikir dan bertindak secara matang dan bijaksana.

c. Dapat memotivasi diri sendiri.

d. Berani dalam mengambil risiko dalam menghadapi tantangan dan perubahan hidup.

e. Bekerja dengan semangat tinggi.

f. Berorientasi pada masa depan dan memiliki komitmen untuk maju.

g. Disiplin.

h. Mengatakan hal-hal yang optimis dalam menghadapi masalah.

Penelitian ini bertujuan untuk menguji secara empirik hubungan antara secure attachment dan kecerdasan adversitas dengan motivasi berprestasi pada siswa single parent.

Berdasarkan dari teori-teori diatas maka dalam penelitian ini hipotesis yang diajukan adalah ada hubungan antara secure attachment dan kecerdasan adversitas dengan motivasi berprestasi pada siswa single parent.

\section{Metode Penelitian \\ Instrumen Penelitian}

Motivasi berprestasi akan diungkap dengan skala motivasi berprestasi yang disusun berdasarkan aspek-aspek motivasi berprestasi yang dikemukakan oleh Asnawi (2002) yang terdiri dari mengambil tanggung jawab atas perbuatannya, memperhatikan umpan balik tentang perbuatannya, mempertimbangkan resiko dan kreatif-inovatif. Tingkat motivasi berprestasi dapat terlihat dari perolehan skor skala hasil pengisian skala yang diharapkan semakin tinggi skor yang diperoleh dari skala motivasi berprestasi maka semakin tinggi motivasi berprestasi, sebaliknya semakin rendah skor yang diperoleh dari motivasi berprestasi maka menunjukkan semakin rendah motivasi berprestasi.

Secure Attachment adalahketerikatan atau kepercayaan rasa aman yang diberikan orang tua atau pengasuh kepada anak berupa kasih sayang yang mengarah pada pengembangan rasa percaya diri, sikap atau ego yang kuat sehingga akan menentukan kesuksesan dalam menghadapi masalah. Secure attachment akan diungkap dengan skala secure attachment yang disusun berdasarkan karakteristik individu yang memiliki secure attachment yang dikemukakan oleh Benokraitis (1996) yang terdiri dari sikap hangat dalam 
berhubungan dengan orang lain, tidak terlalu bergantung pada orang lain, tidak akan menjauhi orang lain, sangat dekat dengan orang yang sangat disayanginya, lebih empati terhadap orang lain, sangat percaya pada orang yang disayangi dan lebih nyaman bersama orang yang disayangi.Tingkat secure attachment dapat terlihat dari perolehan skor skala hasil pengisian skala yang diharapkan semakin tinggi skor yang diperoleh dari skala secure attachment maka semakin tinggi secure attachment, sebaliknya semakin rendah skor yang diperoleh dari secure attachment maka menunjukkan semakin rendah secure attachment.

Kecerdasan adversitas akan diungkap dengan skala kecerdasan adversitas yang disusun berdasarkan karakteristik individu yang memiliki kecerdasan adversitas yang dikemukakan oleh Stoltz (2000) yang terdiri dari optimis, gigih, dan ulet dalam menghadapi masalah, berpikir dan bertindak secara matang dan bijaksana, dapat memotivasi diri sendiri, berani mengambil risiko dalam menghadapi tantangan dan perubahan hidup, bekerja dengan semangat tinggi, berorientasi pada masa depan dan memiliki komitmen untuk maju, disiplin, dan mengatakan hal-hal yang optimis dalam menghadapi masalah.Tingkat kecerdasan adversitas dapat terlihat dari perolehan skor skala hasil pengisian skala yang diharapkan semakin tinggi skor yang diperoleh dari skala kecerdasan adversitas maka semakin tinggi kecerdasan adversitas, sebaliknya semakin rendah skor yang diperoleh dari kecerdasan adversitas maka menunjukkan semakin rendah kecerdasan adversitas.

Populasi dalam penelitian ini adalah siswa SMAN 1 Bangsri. Teknik pengambilan sampel yang digunakan adalah teknik purposive sampling, pertimbangan pengambilan sampel penelitian ini adalah siswa yang tinggal dengan orang tua tunggal (single parent). Berdasarkan uraian tersebut dalam penelitian ini jumlah sampel yang digunakan sebanyak 36 (tiga puluh enam) siswa SMAN 1 Bangsri yang tinggal dengan orang tunggal (single parent).

\section{Metode Pengumpulan Data}

Metode yang digunakan dalam penelitian ini adalah metode pengumpulan data yaitu skala. Adapun skala yang dibuat peneliti dalam penelitian ini adalah skala motivasi berprestasi, skala secure attachment, dan skala kecerdasan adversitas.

\section{Metode Analisis Data}

Metode analisis data yang digunakan dalam penelitian ini adalah metode statistika. Metode statistika yang dipakai dalam penelitian ini adalah teknik Product Moment. 
Hasil Penelitian

\section{Uji Validitas dan Reliabilitas}

Hasil Uji Validitas

\section{Skala Motivasi Berprestasi}

Pada uji validitas tahap 1 skala motivasi berprestasi menunjukkan, dari 40 item terdapat 14 item yang gugur dengan koefisien validitas sebesar 0,018 sampai 0,376 . Pada tahap 2 dari 26 item terdapat 1 item yang gugur dengan koefisien validitas sebesar 0,209 . Pada tahap 3 menunjukkan 25 item yang valid dengan koefisien validitas berkisar antara 0,353 sampai dengan 0,658.

\section{Skala Secure Attachment}

Uji validitas tahap 1 skala secure attachment menunjukkan dari 42 item, terdapat 14 item yang gugur dengan koefisien -0,073 sampai dengan 0,292. Pada tahap 2 dari 28 item terdapat 1 item yang gugur dengan koefisien validitas sebesar 0,250 . Pada tahap 3 menunjukkan 27 item yang valid dengan koefisien validitas berkisar antara 0,355 sampai dengan 0,792.

Skala Kecerdasan Adversitas

Uji validitas tahap 1 skala kecerdasam adversitas menunjukkan dari 40 item, terdapat 11 item yang gugur dengan koefisien -0,164 sampai dengan 0,281. Pada tahap 2 dari 28 item terdapat 4 item yang gugur dengan koefisien validitas sebesar 0,231 sampai dengan 0,284. Pada tahap 3 dari 24 item, terdapat 1 item yang gugur dengan koefisien validitas sebesar 0,294. Pada tahap 4 menunjukkan 23 item yang valid dengan koefisien validitas berkisar antara 0,345 sampai dengan 0,791.

\section{Uji Asumsi}

Uji Normalitas Sebaran

Uji normalitas pada variabel secure attachment menunjukkan nilai K-SZ sebesar 0,774 dan $p$ sebesar $0,588(p>0,05)$ sedangkan uji normalitas pada variabel kecerdasan adversitas menunjukkan nilai K-SZ sebesar 0,667 dan p sebesar 0,765 $(p>0,05)$ dan uji normalitas pada variabel motivasi berprestasi menunjukkan nilai KSZ sebesar 0,640 dan $p$ sebesar 0,807 ( $p>0,05)$.

Uji Linieritas Hubungan

Hasil uji linieritas di atas menunjukkan korelasi antara motivasi berprestasi dengan secure attachment. Hal ini ditunjukkan dengan hasil yang diperoleh dari nilai $F$ linier sebesar 1,082 dengan $p$ sebesar $0,445 \quad(p<0,05)$. Angka tersebut menunjukkan bahwa adanya hubungan bersifat linier. 
Hasil uji linieritas di atas menunjukkan korelasi antara motivasi berprestasi dengan secure attachment. Hal ini ditunjukkan dengan hasil yang diperoleh dari nilai $F$ linier sebesar 0,967 dengan $p$ sebesar $0,523 \quad(p<0,05)$. Angka tersebut menunjukkan bahwa adanya hubungan bersifat linier.

Uji Hipotesis

Hipotesis Mayor

Berdasarkan perhitungan di atas menunjukkan bahwa koefisien korelasi dari kedua $r_{x y}$ sebesar 0,832 dengan taraf signifikan $p$ sebesar $0,000(p<0,01)$ ini berarti ada hubungan yang sangat signifikan antara secure attachment dan kecerdasan adversitas dengan motivasi berprestasi.

Hipotesis Minor

Berdasarkan hasil analisis diketahui bahwa besarnya korelasi antara kedua variabel $r_{x y} 0,802$ dengan taraf signifikan $p$ sebesar $0,000 \quad(p<0,01)$. Hal ini menunjukkan bahwa ada hubungan positif yang sangat signifikan antara secure attachment dengan motivasi berprestasi, artinya semakin tinggi secure attachment maka semakin tinggi motivasi berprestasi, sebaliknya semakin rendah secure attachment maka semakin rendah motivasi berprestasi. Dengan demikian hipotesis minor pertama dalam penelitian ini diterima.

Berdasarkan hasil analisis diketahui bahwa besarnya korelasi antara kedua variabel $r_{x y} 0,795$ dengan taraf signifikan $p$ sebesar $0,000 \quad(p<0,01)$. Hal ini menunjukkan bahwa ada hubungan positif yang sangat signifikan antara kecerdasan adversitas dengan motivasi berprestasi, artinya semakin tinggi kecerdasan adversitasmaka semakin tinggi motivasi berprestasi, sebaliknya semakin rendah kecerdasan adversitas, maka semakin rendah motivasi berprestasi. Dengan demikian hipotesis minor pertama dalam penelitian ini diterima.

\section{Diskusi}

Subyek dalam penelitian ini adalah siswa yang tinggal dengan orang tua tunggal (single parent). Terwujudnya motivasi berprestasi pada anak tentunya perlu dukungan dan perhatian dari keluarga terutama dari kedua orang tua. Orang tua mempunyai tugas yaitu untuk membimbing dan mendidik anak-anaknya. Dalam setiap keluarga, tentunya pola asuh yang diberikan kepada anak juga berbeda. Keluarga merupakan satu kesatuan lingkungan sosial pertama bagi anak dan tempat anak mendapatkan perlindungan, kasih sayang serta rasa aman (Sari, 2011). 
Salah satu bentuk keterikatan kasih sayang yang dimulai dari kehidupan individu adalah secure attachment. Secure attachment merupakan keterikatan yang aman yang diberikan orangtua pada anak secara konsisten dan responsif yang berupa kasih sayang dalam menumbuhkan rasa aman dan kasih sayang (Maentiningsih, 2008).

Menurut Santrock (1999), "remaja dengan secure attachment akan terpenuhi rasa aman dan kasih sayang dari orangtua sehingga mampu mencapai kebutuhan penghargaan dari orang lain (aktualisasi diri) khususnya dalam bentuk prestasi" (Maentiningsih, 2008).

Selain secure attachment, faktor lain yang erat kaitannya dengan motivasi adalah kecerdasan adversitas (Syahid, 2014). Menurut McClelland (1987), "motivasi berprestasi sebagai suatu usaha untuk mencapai kesuksesan, yang bertujuan berhasil dalam persaingan dengan berpedoman pada ukuran keunggulan tertentu". Menurut Stoltz (2005), "seseorang yang memandang dan mampu mengubah kesulitan atau hambatan sebagai suatu tantangan dan peluang adalah seseorang yang akan mampu terus berjuang dalam situasi apapun sehingga merekalah yang akan mencapai kesuksesan. Seseorang yang terus berjuang dan berkembang pesat adalah seseorang yang memiliki kecerdasan adversitas yang tinggi" (Nugraha, 2011).

Menurut Maentiningsih (2008), Adanya peran dari kedua orangtua yang cukup dominan yang tidak hanya memberikan kasih sayang saja namun dukungan serta rasa aman yang didapat dari orangtua akan menyebabkan remaja memiliki motivasi berprestasi yang tinggi.

Menurut hasil penelitian Sokun \& Akinade menyatakan bahwa anak yang tinggal dan diasuh dengan satu orang tua memiliki self esteem, motivasi berprestasi, dan prestasi akademik yang rendah dibanding dengan meraka dari keluarga yang lengkap, dimana keduanya yaitu ayah dan ibu menjadi orang tua. (Obieke, 2013).

Menurut McClelland (Nugraha, 2011), "motivasi berprestasi sebagai suatu usaha untuk mencapai kesuksesan, yang bertujuan berhasil dalam persaingan dengan berpedoman pada ukuran keunggulan tertentu". Menurut Stoltz (2000), "kecerdasan adversitas merupakan pemahaman penting tentang apa yang dibutuhkan untuk mencapai kesuksesan. Sukses tidaknya individu dalam kehidupan ditentukan oleh kecerdasan adversitas, dimana kecerdasan adversitas dapat memberitahukan sejauh mana individu mampu bertahan dan mengatasi kesulitan yang dihadapi, individu mana yang mampu mengatasi kesulitan dan yang tidak 
mampu, individu mana yang akan memenuhi harapan dan potensi serta yang akan gagal, dan individu yang akan menyerah dan yang akan bertahan".

Besarnya pengaruh secure attachment dan kecerdasan adversitas terhadap motivasi berprestasi tampak pada besarnya sumbangan efektif sebesar $69,3 \%$ yang berarti masih terdapat $30,7 \%$ faktor lain yang mempengaruhi motivasi berpestasi. Adapun besarnya sumbangan efektif variabel secure attachment terhadap motivasi berprestasi sebesar $64,3 \%$ dan besarnya sumbangan efektif variabel kecerdasan adversitas terhadap motivasi berprestasi sebesar $63,3 \%$.

Berdasarkan norma kategori secure attachment diperoleh bahwa secure attachment tergolong sedang. Hal ini diketahui dari hasil respon subyek pada item dalam skala yang menunjukkan prosentase secure attachment terbesar pada tingkat sedang, dengan perincian sebagai berikut: tingkat secure attachment sangat rendah ada 4 orang $(11,1 \%)$, tingkat secure attachment rendah ada 8 orang $(22,2 \%)$, tingkat secure attachment sedang ada 11 orang $(30,6 \%)$, tingkat secure attachment tinggi ada 9 orang (25\%), dan tingkat secure attachment sangat tinggi ada 4 orang $(11,1 \%)$.

Berdasarkan norma kategori kecerdasan adversitas diperoleh bahwa kecerdasan adversitas tergolong tinggi. Hal ini diketahui dari hasil respon subyek pada item dalam skala yang menunjukkan prosentase kecerdasan adversitas terbesar pada tingkat sedang, dengan perincian sebagai berikut: tingkat kecerdasan adversitas sangat rendah ada 2 orang (5,5\%), tingkat kecerdasan adversitasrendah ada 11 orang $(30,6 \%)$, tingkat kecerdasan adversitassedang ada 10 orang $(27,8 \%)$, tingkat kecerdasan adversitastinggi ada 11 orang $(30,6 \%)$, dan tingkat kecerdasan adversitassangat tinggi ada 2 orang (5,5\%).

Berdasarkan norma kategori motivasi berprestasi diperoleh bahwa motivasi berprestasi tergolong sedang. Hal ini diketahui dari hasil respon subyek pada item dalam skala yang menunjukkan prosentase motivasi berprestasi terbesar pada tingkat sedang, dengan perincian sebagai berikut: tingkat motivasi berprestasi sangat rendah ada 3 orang (8,3\%), tingkat motivasi berprestasi rendah ada 7 orang (19,5\%), tingkat motivasi berprestasi sedang ada 15 orang $(41,7 \%)$, tingkat motivasi berprestasi tinggi ada 8 orang $(22,2 \%)$, dan tingkat motivasi berprestasi sangat tinggi ada 3 orang $(8,3 \%)$.

\section{Simpulan}

Berdasarkan hasil penelitian dan analisis data yang dilakukkan menunjukkan hasil $r_{x 1,2 y}$ sebesar 0,832 dengan taraf signifikan $p$ sebesar $0,000(p<0,01)$, sehingga 
dapat disimpulkan bahwa ada hubungan yang sangat signifikan antara secure attachment dan kecerdasan adversitas dengan motivasi berprestasi. Hipotesis yang diajukan dalam penelitian ini diterima. Sumbangan efektif secure attachment dan kecerdasan adversitas sebesar $69,3 \%$.

\section{Saran}

Bertitik tolak pada hasil penelitian yang telah diuraikan di atas, maka penulis mengajukan saran sebagai berikut:

1. Bagi remaja/siswa yang memiliki motivasi berprestasi rendah dapat memperbaiki motivasi berprestasinya dengan cara meningkatkan kecerdasan adversitasnya, misalnya dengan mengikuti organisasi PKS (Patroli Keamanan Sekolah), Passus (Pasukan Khusus), dan OSIS yang mengajarkan tanggung jawab dan kedisiplinan, atau mengikuti organisasi Pinkor (Pusat Informasi Konseling Remaja) yang mengajarkan bagaimana cara menyelesaikan permasalahan yang dialami diri sendiri atau orang lain.

2. Bagi peneliti lain disarankan agar dapat menyempurnakan hasil penelitian ini dari sisi penyempurnaan item dan melibatkan pengaruh faktor-faktor lain selain secure attachment dan kecerdasan adversitas. 


\section{DAFTAR PUSTAKA}

Asnawi. S (2002). Teori Motivasi. Jakarta : Studio Pers

Benokraitis, N. V (1996). Marriages and Families $2^{\text {nd }}$ Edition: Changes, Choices and Constraint. New Jersey : Prentice-Hall Inc.

Djaali.. H. (2014). Psikologi Pendidikan. Jakarta : Bumi Aksara

Fahmi. S. (2008). Adversity Quotient (Aq) Dan Motivasi Berprestasi Pada Siswa Program Akselerasi Dan Program Reguler. Skripsi, Fakultas Psikologi : Universitas Islam Indonesia

Hartaji, Dkk. (2009). Motivasi Berprestasi Pada Mahasiswa Yang Berkuliah Dengan Jurusan Pilihan Orang Tua. Skripsi, Fakultas Psikologi : Universitas Gunadarma

Isti'anah. (2010). Kepribadian Anak pada Keluarga Single Parent. Skripsi, Fakultas Dakwah : Universitas Islam Negeri Sunan Kalijaga Yogyakarta Lestari, A. F. (2008). Usaha Pembina Dalam Menumbuhkan Rasa Percaya Diri Pada Remaja Anak Asuh Di Panti Asuhan Yatim Piatu 'Aisyiyah Serangan Yogyakarta. Skripsi, Fakultas Psikologi : Universitas Islam Negeri Sunan Kalijaga Yogyakarta.

Maentiningsih, D. (2008). Hubungan Antara Secure Attachment Dengan Motivasi Berprestasi Pada Remaja.Jurnal Psikologi, Fakultas Psikologi : Universitas Gunadarma. Di Unduh (12-07-2015)

Mahmoud, A. (2001). English Teachers' Achievement Motivation In The Ight Of Some Variables In Tulkarm Government Schools. Journal Of Al-Quds Open University For Research And Studies : No. 24 (1) July 2011

Nugraha, R. A. (2011). Pengaruh Pelatihan Kecerdasan Adversitas Terhadap Motivasi Berprestasi Pada Siswa Kelas X Di Sma Negeri 8 Surakarta. Skripsi, Fakultas Psikologi : Universitas Sebelas Maret Surakarta

Obieke, U. A. (2013). Single Parenting, Psychology Well-Being And Academic Performance Of Adolescents In Lagos Nigeria. Journal Of Emerging Trends In Educational Research And Policy Studies (Jeteraps) 4(1): 112-117 : Department Of Educational Foundation, University Of Lagos, Nigeria

Rohmawati, S. (2010). Hubungan Antara Secure Attachment dan Dukungan Sosial dengan Self Disclosure pada Santri Pondok Pesantren Al-Muayyad Surakarta. Skripsi, Fakultas Psikologi : Universitas Sebelas Maret 
Sari, D. M. (2011). Hubungan Antara Persepsi Remaja Terhadap Pola Asuh Ibu Sebagai Orang Tua Tunggal Dengan Motivasi Berprestasi. Skripsi, Fakultas Psikologi : Universitas Muhammadiyah Surakarta

Sitota, G. (2014). The Relationship Between Adolescent's Family Structures and Their Academic Achievement Motivation of Sebeta Senior Secondary School Students. Thesis, College of Education and Behavioral Studies : Addis Ababa University

Stoltz, P. G. (2000). Adversity Quotient. Mengubah Hambatan Menjadi Peluang. Jakarta : Grasindo

Syahid, N. (2014). Hubungan Antara Adversity Quotient Dan Motivasi Berprestasi Siswa Kelas Xi Ma Ali Maksum Kraapyak Yogyakarta. Skripsi, Fakultas Psikologi : Universitas Islam Negeri Sunan Kalijaga Yogyakarta 